\title{
Environmental impact of the Energía Costa Azul LNG terminal at Ensenada, B.C., México
}

\author{
M. Quintero-Núñez ${ }^{1}$, C. del C. Sanchez-Sanchez ${ }^{2}$, \\ R. García-Cueto ${ }^{1}$, N. Santillán-Soto ${ }^{1}$, S. Ojeda-Benítez ${ }^{1} \&$ \\ N. Velázquez-Limón ${ }^{1}$ \\ ${ }^{I}$ Instituto de Ingeniería, Universidad Autónoma de Baja California, \\ México \\ ${ }^{2}$ Escuela de Ingeniería, Universidad Autónoma de Sinaloa, México
}

\begin{abstract}
In Mexico there are three liquid natural gas (LNG) terminals supplied from places such as Palmira, Tamaulipas, Manzanillo, Colima and Costa Azul, being the latest located 23 kilometers north of Ensenada, Baja California (B.C.). The installation of the most recent plant at Costa Azul, which is an area abundant in terrestrial and marine resources, takes advantage of the only cultural prehistoric remain between Ensenada and Tijuana. The profile that was associated to the Coastal Tourist Corridor between Tijuana and Ensenada was changed to a tourist-industrial one to describe the new land's use. Shell International Gas Limited in association with Sempra Energy LNG Corp. constructed a receiving terminal in the zone with a capacity of 1,049,866 mmcf/daily. The Shell/Sempra LNG terminal is located to a distance of just 3 kilometers from Bajamar, which is a tourist complex, exposing the habitants to accidents from the terminal. The objective of this work is to analyze the environmental, cultural and labor impact that the construction of this plant provokes due to its proximity to tourist populated areas where they can be reached by a fire or explosion generated by an accident originated within and the safety measures that this LNG plant is obliged to abide.

Keywords: liquid natural gas terminal, risk, Energia Costa Azul, Ensenada, México, environmental impact.
\end{abstract}




\section{Introduction}

Liquefied natural gas (LNG) is a secondary form of energy that is derived from primary energies as associated gas and non-associated gas. Natural gas is present over the world, either in deposits located under the earth or in the oceans. Although abundant, but its gaseous state and the difficulty of its transportation prevented for a long time the massive use of the natural gas.

Its use was limited to a few locations where the gas deposits were close to the consuming centers. The small consumption remained until the development of its transportation using gas pipelines that allowed covering long distances and connecting the deposits of gas to the consuming centers. From this moment onwards, the natural gas started to play a more important role in the generation of energy. Thus, the gas coming from a deposit in continuous flux is liquefied and stored in big tanks, waiting to be loaded in special ships, later to be transported to other continents, either close or distant from the gas producing area. In the other end, it is constructed a receiving terminal, with tanks of high capacity to store the fluid and to serve the demand fluctuations of the market [1].

There is a LNG terminal in Baja California known as Energia Costa Azul that it is owned by Sempra, an American company located in San Diego, CA, USA. It was officially inaugurated in August 2008, but it construction started in 2003.

Baja California does not extract nor produce natural gas and does not have known sources of this type of energy, however in the last decade its consumption has increased. Baja California is not connected to the Pipeline National System (PNS) and, it does not benefit from the national production of natural gas. The regional consumption is supplied through the importation using pipelines and a liquefied natural gas terminal [2].

According to the Secretary of the Environment and Natural Resources (SEMARNAT by its acronym in Spanish) environmental impact is defined as the "modification of the environment caused directly by the action of man or by nature". This work has the objective to present an evaluation on the potential risks of the Energia Costa Azul LNG terminal, and determine the minimal safe distance that should exist between a LNG terminal and the closest communities in order to avoid or minimize losses of lives and damages and conflicts to neighboring properties, cultural and tourist activities in the event of a catastrophic incident. It also seeks to disseminate and inform the perception of the society to sensible and potential dangerous events by the different outcomes due to the plant construction and operation.

\section{The Energia Costa Azul LNG terminal in México}

The liquid natural gas is a fuel of the present and like any other type of non-renewable energy is limited in nature. The LNG is a form of natural gas that is extracted from gas deposits underground, compressed at extreme cold temperatures $\left(-162^{\circ} \mathrm{C}\right)$ that condense the gas into a liquid to be transported in cargo ships [3], to processing plants where it is converted again to natural gas for its distribution. It is transparent, odorless, non-toxic, and no corrosive and is the 
cleanest fossil oil [4]; its composition is $95 \%$ methane and $5 \%$ ethane, butane, propane, natural gasoline, etc. In its commercialized form, it does not contain sulphur; therefore does not generate $\mathrm{SO}_{2}$. Its emissions of nitrogen oxides and carbon dioxides are smaller than those generated by oil and coal [5].

In the world there are 83 regasification LNG terminals in 23 countries, with a total capacity of 572 millions of tons (1,276 millions of cubic meters of LNG). During the recent years the principal corporations of energy have installed regasification terminals in Mexico. Two of these terminals are found north east of the country, at Altamira and Tamaulipas, in the Gulf of Mexico, and Northwest at Ensenada, Baja California in the Pacific Ocean and the third one at Manzanillo, Colima, in the South of the country also in the Pacific Ocean [6].

At the beginning of 2008, Sempra initiated the operation of an LNG terminal at Costa Azul with a capacity of 1,049,866 mmcf/daily in the West coast of Mexico at Ensenada, Baja California [7]. A general description of the Costa Azul LNG terminal installed in Mexico is given in table 3.

Table 1: $\quad$ Principal characteristics of the Costa Azul LNG terminal installed in México.

\begin{tabular}{|l|c|c|c|c|}
\hline \multicolumn{5}{|c|}{ CHARACTERISTICS } \\
\hline $\begin{array}{l}\text { Supplying } \\
\text { source }\end{array}$ & $\begin{array}{c}\text { Initial } \\
\text { capacity for } \\
\text { exportation }\end{array}$ & $\begin{array}{c}\text { Investment } \\
\text { cost }\end{array}$ & $\begin{array}{c}\text { Starting } \\
\text { Operation } \\
\text { date }\end{array}$ & $\begin{array}{c}\text { Ownership } \\
\text { enterprise }\end{array}$ \\
\hline Indonesia & $\begin{array}{c}\$, 049,866 \\
\text { mmcf/daily }\end{array}$ & $\begin{array}{c}\text { Million } \\
\text { Dlls. }\end{array}$ & $\begin{array}{c}\text { August 28 } \\
2008\end{array}$ & $\begin{array}{c}\text { Sempra } \\
\text { Energy }\end{array}$ \\
\hline
\end{tabular}

Source: CFE, SECEX, El Noticiero, 2012.

A liquefaction plant has an average cost between 1 and 2 billion of dollars, a cargo ship between 1.5 and 2.5 billion of dollars, and the regasification plant installed in Baja California has an average cost of 500-1000 million dollars. Adding the average costs the LNG total chain rises to 4 to 5 billion of dollars [6].

\subsection{Costa Azul: a jewel of the Baja Californians}

Baja California is located geographically to the northwest of the country and is found within the area known as the Pacific Ring of Fire, honorific place that shares with the immediate area of California (CA), USA. Costa Azul is located 23 kilometers north of Ensenada (Fig. 1), is an area of abundant natural resources, however this zone was selected for the implantation of a LNG terminal [6].

Costa Azul is an important component of the cultural heritage of the North of Baja California and South of California, it has been recognized as an area abundant in terrestrial and marine resources, and it is the only prehistorical cultural area that remains between Ensenada and Tijuana [8]. The studies conducted in coastal human settlements close to the premises of Costa Azul, have provided data that oscillates between 4000 to 10,000 years ago. In these 
coastal settlements the old human groups processed their food and artifacts from hunting and fishing, this information was obtained from the accumulation of sea shells, stone ships excortication, several ceramics hand fragments, mortars and human bones [9].

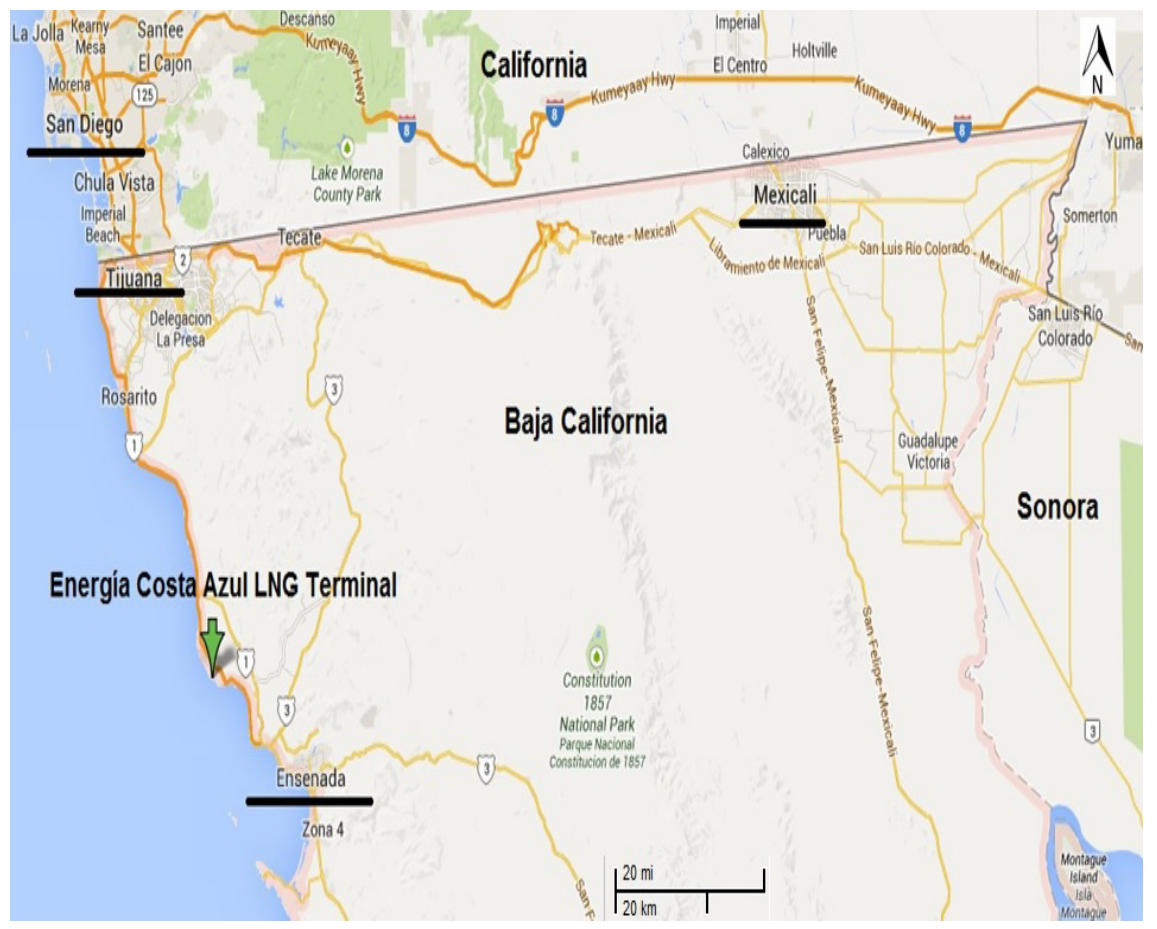

Figure 1: Location of Energia Costa Azul LNG terminal.

This coastal area provides the habitat for two species in danger of extinction, the Ferro cactus and the Crotalo rubus and to a high diversity of biological and endemic species. Its magnificent coastal sceneries, its well preserved rare and cultural resources, make of Costa Azul an area key to understand patterns of human settlements, cultural changes, and history of the region, which makes the site an important area to be preserved through the adequate manage of its natural resources to avoid its destruction and the continuance of its heritage for new generations to enjoy [8].

Bajamar is a short distance from Costa Azul, where it also has been found numerous old artifacts [8]. Once the Costal Tourist Corridor (COTUCO for its acronym in Spanish) between Tijuana-Ensenada was changed to tourist-industrial, Shell International Gas Limited and Sempra Energy LNG Corp. associated to construct a LNG receiving terminal in the zone of Costa Azul. The Shell-Sempra LNG Terminal is located to a distance of 3 kilometers from Bajamar, which is a tourist complex in an area of 130 hectares. The site extends over a coastal soil area of 20 hectares approximately [6]. 


\subsection{Characteristics of the LNG terminal at Costa Azul}

Sempra Energy is a company (holding) of services of energy with operations in USA, Mexico and other countries in Latin America. The company, through its subsidiaries, generates electricity, distributes natural gas, operate natural gas pipelines and installations for its storage. Furthermore, it manages a project of eolic energy in Baja California [2]. To justify the project was used the following criteria:

1. The need of energy, indispensable condition to support the regional development.

2. The demand's growth of the natural gas in BC estimated between 2004 and 2013 to reach an increase of $10.7 \%$ per year and projected to escalate to double by 2020 .

3. BC is not part of the national energy infrastructure distribution.

4. BC imports all the gas from USA and is located at the end of its southwest pipelines system (which is a disadvantage in prices disponibility)

5. The production of gas in USA and Canada has been decreasing while the demand has increased in California.

6. The two entities (CA and $\mathrm{BC}$ ), integrated in a single geographic region share the problem and require an integral solution to their energy needs.

At the beginning of 2008, the region begun to diversify its energy supplies with the operation of the new Energia Costa Azul LNG Terminal; it became the first terminal of regasification of open access [2].

\subsection{Mexico: target for the installation of LNG plants}

Reasons behind the interest of foreign companies in the construction of receiving LNG terminals in Mexico [3], close to the border with USA are:

1. The proximity of the market of high demand from the USA.

2. Avoid the strict environmental laws.

3. Apparent lesser local opposition in Mexico for the location of the LNG terminals nearby existing populations.

4. To get the control of a great part of the NG market in the Northwest of Mexico and South of California.

For these reasons, promoting a clear transference of risks, it has precipitated the construction of terminals north of Mexico, in areas close to the border line for rapid access to the USA markets. The site of Costa Azul was selected after an evaluation of the nearest coastal sites close to the US-Mexican border, the final decision was made dividing the zones and taking in consideration the proximity to population centers as much as the availability of deep waters. However, said evaluation did not prevent the installation of the Energia Costa Azul LNG terminal in an unsafe distance to Bajamar. Furthermore, the trajectory of the pipeline towards Tijuana and California (USA) runs close to various populated zones and impacts different natural areas [6]. 
The Energia Costa Azul LNG terminal at Ensenada was one of the first of its kind to be submitted to the procedure of public outreach. The authority approved this project based on not finding contradictions in the juridical legal laws applicable - programs of urban development or ecological plans for legal management [5].

Unfortunately, the generation of employment in this type of industry is minimum and the jobs generated for the nationals are blue collar type, therefore it cannot be considered an important source of employment [10].

As a consequence of the installation of the LNG plant, Costa Azul in particular has decreased its fishing activity, and the tourism has been affected as well. Considering that Ensenada does not count with contingency plans, more terminals should not be installed or approved until the danger to populated areas is further evaluated and studied, as well as the disparity of the hiring process actually in favor of foreign personnel be addressed [4].

\section{Environmental impacts at Costa Azul due to installation of a LNG plant}

\subsection{Air}

The environmental impacts associated with LNG are known regularly as caused by the generation of emissions to the air, including green house gases (GHG). Apart from the combustion, may be present environmental impacts, like the increase of $\mathrm{CO}_{2}$ emissions to the atmosphere due to the processes to liquefy, transport and regasify the LNG [6]. This fuel is made of $95 \%$ methane, a GHG, that may escape in the form of vapor clouds (inflammable) or leak in pipes and storage tanks.

Although natural gas is less harmful compared to other fossil fuels historically used, the gas combustion produces large quantities of atmospheric pollutants which deteriorate the environment and compromise the community's health [2].

\subsection{Flora and fauna}

The Energia Costa Azul LNG terminal is located close to a populated area, on a fragile Mediterranean coastal terrace on the pacific coast of Baja California (that includes an arqueological site) where a group of fishermen have been practicing a sustainable management of the marine resources. Additionally, the extraction and expulsion of millions of litters of sea water may disturb the marine ecosystem affecting, the migration of the grey whales that return every year to this location to reproduce, such disturbance may be increased by the traffic of LNG tanker ships that pollute and can interrupt the reproductive process of this specie [6]. 


\subsection{Water}

The Energia Costa Azul LNG terminal requires the daily extraction, disinfection and subsequently the disposal of 500 to 1000 million liters of chlorinated sea water, this process is highly toxic for the marine life, since damages the reproduction, feeding, and breathing of the species. Additionally may cause mutagenic effects. The temperature at which the water is disposed is $20^{\circ} \mathrm{C}$ degrees colder than the water of the ocean magnifies the toxic impacts of the chlorinated sea water. In the sea, the disposed chlorine does not dissolve; instead it is adhered to other substances to form organ chlorine compounds that maintain their toxicity a long time $[5,6]$.

\subsection{Soil}

The area where the Energia Costa Azul LNG terminal was built is a designated seismic location. The plant is located at the vortice of a geological fault (San Andreas) and it was revealed there is no information about the working and technical conditions the storage tanks were built to deal with a seismic event.

Furthermore, the company has not presented maps and plans of pipes routes, where they would be crossing and any contingency plans in the event of any accidents that can delimit liabilities to force the building company to provide liability insurance against them, where the municipality would be one the beneficiaries, and necessary to regulate the company's activities. Sempra is a global industry that transports LNG from Indonesia and impacts the labor, culture and environment of the area where it is located. Sempra is already in Mexico since USA did not authorize the LNG terminal in California and the community rejected it. It alters the visual scene, and impacts the economy of the fishermen and the tuna ranches [4].

\subsection{Latent risks for the installations of LNG plants}

The USA has identified the LNG installations and the ships as elements of high risk [6]. There are two cases that may occur when installing an LNG terminal, the first is a fire and the second is an explosion. For the case of a fire, which is an impact of radiant energy, the biggest concern is in the area of vaporization which a change of phase from liquid to gas, and the transfer of heat with sea water represents the most vulnerable zone of the installation. In case of an explosion, which is called over pressure wave, the more critical point of the plant is the vaporizers [4].

In accordance with the Integral Services in Environmental Training (SICAP for its acronym in Spanish) a consultancy firm, the LNG company presents a risk of explosion grade 8 , that according to the risks' levels, it means that within the next 20 years will occur a sinister based on the statistics of spills at world level; besides, considering the enormous amount of leaks of gas that the process provides, the intemperisms, weathering and aleatory meteors that are present if an explosion may occur. The effect will be lethal for human lives and constructions (Fig. 2) within a radius of $2.0 \mathrm{Km}$ (inner circle). 
Additionally, the trans peninsular or scenic Tijuana-Ensenada highway is located in the $2 \mathrm{~km}$ radio and would be affected. Second degree burns to stakeholders and structural damage could occur to residences in a $2.7 \mathrm{Km}$ radio (middle circle) and rupture of house window glasses. On the north part of the middle circle is located a residential development. Within the outer circle with a radio of $4.0 \mathrm{Km}$. would be produced ear and body injury [4].

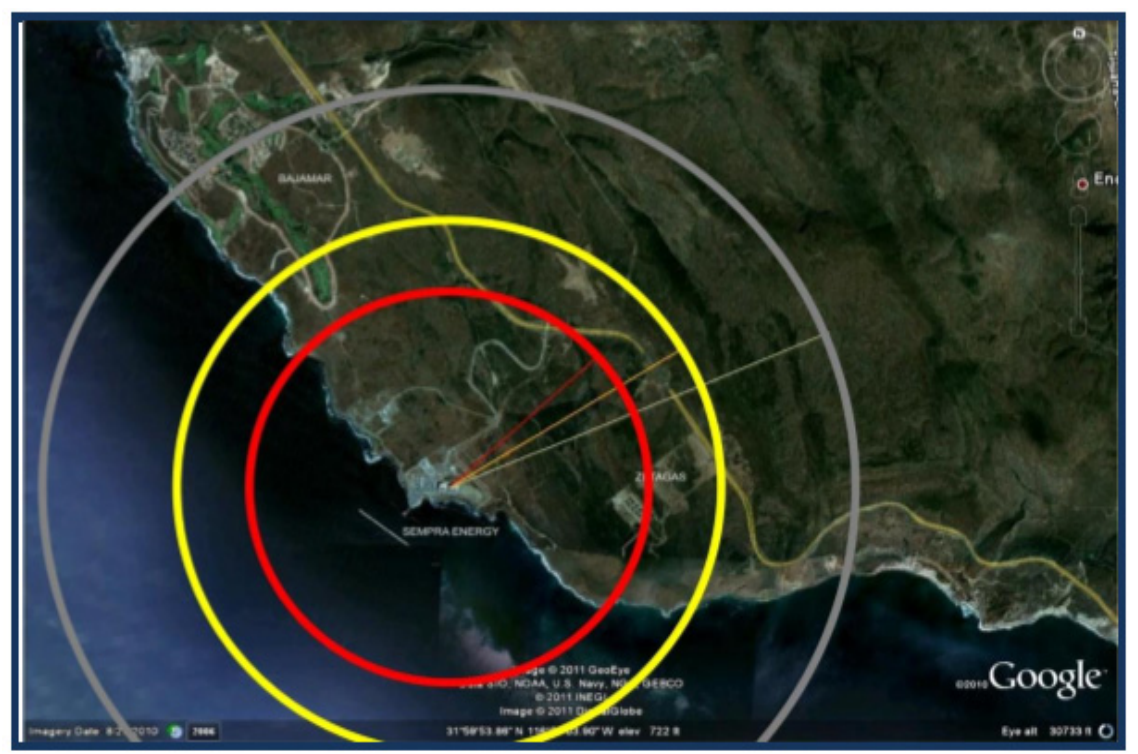

Source: Comisión de Medio Ambiente y Recursos Naturales, 2011.

Figure 2: Buffer area of the Energia Costa Azul LNG terminal.

As it may be observed, the opposition to the LNG terminals is based on fears to the possibility of a leak of a gas cloud that could burn or explode. The Sandia National Laboratories, at Albuquerque, Arizona, published in December of 2004 "the analysis of spills of LNG tanquer ships", and established for the majority of the plants two action areas focused on hazards (the first within the first mile which is of a very high flammability, and the second in the event a rupture occurs). This study seeks to pressure the coast guard authority to establish a security zone; in an area of two miles range of any human settlement [11].

The question is who would assume the cost and the responsibility of the security of the installations of Energia Costa Azul LNG terminal for the environment and the population of Baja California? If a course of action is not taken in that direction it will be clear that companies will abuse the Mexican territory due to lack of regulations, limited community participation, and poor enforcement of security standards as in a machine room, a cheap hotel, or the backyard [6]. 


\section{Conclusions}

- The location of the LNG terrestrial reception terminal represents a potential risk for the human settlements in the vicinity of the plant. If a LNG tanker ship or terrestrial storage tank explodes, either by accident or by sabotage, may cause fires of huge magnitude.

- The terrestrial LNG terminal for reception and regasification at Costa Azul produces a serious negative impact on the ecology and the environment for the loads of unremarkable proportions that represents for the sensible local ecosystems.

- The location of the LNG terminal of reception and regasification at Costa Azul, Baja California, has a negative effect on the value of the real state of the tourist and residential developments that already existed in the vicinity of the terminal.

- Total marine and terrestrial studies should be carried out.

- The native community of Baja California should be involved if the site should be utilized to send NG to Baja California and California then it must fulfill the best standards for the stringest regulation existing in either state (CA or $\mathrm{BC})$.

Mexico is in the position to redesign its energy policy and bring it to a right direction, to achieve reliable energy independence, and to avoid or minimize the risks of dependency on imported fossil fuels as well as to control the unlimited concessions to private enterprises to control the Mexican energy sector. The road to follow is towards a truly management of renewable sources of energy in Mexico, which may impulse the economic and social development of the country.

\section{References}

[1] López, A. E., El Gas Natural Licuado (GNL), Petrotecnia, pp. 84-85. Available at http://www.petrotecnia.com.ar/junio12/sin publicidad/GNL.pdf .2012

[2] Muñoz, M. G., Campbell, R., Héctor, E., Díaz, G. E., and Quintero, N. M., Baja California: Perfil Energético 2010-2020, Comisión Estatal de Energía de B.C. 2012

[3] Powers, B., 2002, Evaluación de riesgos potenciales asociados con la ubicación de una planta de GNL aledaña a Bajamar y opciones alternativas viables, Report by Powers Engineering. 2002

[4] Comisión de Medio Ambiente y Recursos Naturales, Informe sobre la Regasificadora Energía-Costa Azul S. de R.L. y C.V. 2011

[5] Juárez, P. J. and Heisler, W. H., Terminal de Recibo Almacenamiento y Regasificación de Gas Natural Licuado: Energía Costa Azul, Informe. 2011 
[6] Moreno, A., Coequyt, J., Albrech, K., Casper, K. and Powers B., Gas natural licuado: fin de la independencia energética, Greenpeace, Informe. 2004

[7] (EIA) Energy Information Administration, Mexico Week: Record Mexican natural gas imports include higher flows from U.S., available at http://www.eia.gov/todayinenergy/detail.cfm?id=11291, 2013

[8] Wilken, R. M., Costa Azul: a threatened cultural landscape (notes for a talk). 2003

[9] Pesenti, C., Enfoque: Gas Natural Licuado en Baja California, Pro Península, pp. 2-3. 2002

[10] Guinea, G., Acosta, M., Navarro, J., González, Ma. C., Acosta, M., Lutz, $\mathrm{J}$. and Lozano, R., Vecinos y organizaciones no gubernamentales de playas de Tijuana contra la gasera Marathon Oil/Gas Natural de Baja California, Manifesto. 2003

[11] Kamp, R., Agosto 2005, Análisis de impactos ambientales y de otros tipos debidos a la planta y tuberías de Gas Natural Licuado (GNL) propuestas por la compañía DKRW, Reporte. Available at http://www.etechinternational.org/new_pdfs/REFINERIAESPANOL2.pdf 